\title{
THE FIRST RECORD OF HYDRURUS FOETIDUS (VILLARS) TREVISAN (OCHROPHYTA: CHRYSOPHYCEAE) IN CROATIA WITH ECOLOGICAL NOTES
}

\author{
Igor Stanković ${ }^{* *}$ \& Patrick Leitner ${ }^{2}$ \\ ${ }^{1}$ Hrvatske vode, Central Water Management Laboratory, Ulica grada Vukovara 220, \\ 10000 Zagreb, Croatia \\ ${ }^{2}$ Institute of Hydrobiology and Aquatic Ecosystem Management, Department of Water, \\ Atmosphere, Environment, University of Natural Resources and Life Sciences, Vienna, \\ Max Emanuel Straße 17, 1180 Vienna, Austria
}

Stanković, I. \& Leitner, P.: The first record of Hydrurus foetidus (Villars) Trevisan (Ochrophyta: Chrysophyceae) in Croatia with ecological notes. Nat. Croat., Vol. 25, No. 2., 223-231, 2016, Zagreb.

During research into phytobenthos, macrophytes and macroinvertebrates in Bijela rijeka River in the Plitvice Lakes National Park in 2015, Hydrurus foetidus (Villars) Trevisan was recorded for the first time in Croatia. H. foetidus is a macroalga belonging to the group of golden algae or chrysophytes (Ochrophyta: Chrysophyceae). It is a stenotherm species and an exclusive inhabitant of cold mountain streams, preferring a fast-flow environment and riffles. The identification of $H$. foetidus in Bijela rijeka River indicates high water quality despite the highly modified river morphology and severe anthropogenic impacts received in Plitvički Ljeskovac village.

Key words: Bijela rijeka River, National Park Plitvice Lakes, Hydrurus foetidus, small mountain river, karstic river, new record.

Stanković, I. \& Leitner, P.: Prvi nalaz alge Hydrurus foetidus (Villars) Trevisan (Ochrophyta: Chrysophyceae) u Hrvatskoj i njezine osnovne ekološke značajke. Nat. Croat., Vol. 25, No. 2., 223-231, 2016, Zagreb.

Tijekom istraživanja fitobentosa, makrofita i makrozoobentosa u Bijeloj rijeci u NP Plitvička jezera u 2015. godini, po prvi je puta u Hrvatskoj utvrđena vrsta Hydrurus foetidus (Villars) Trevisan. H. foeti$d u s$ je makroskopski vidljiva alga iz skupine zlatnožutih algi (Ochrophyta: Chrysophyceae). To je stenotermna vrsta, isključivi stanovnik hladnih gorskih tekućica koja preferira plitke dijelove s brzom vodenom strujom. Nalaz alge $H$. foetidus ukazuje na visoku kvalitetu vode u Bijeloj rijeci, unatoč njenoj morfološkoj degradiranosti i antropogenom utjecaju naselja Plitvički Ljeskovac.

Ključne riječi: Bijela rijeka, Nacionalni park Plitvička jezera, Hydrurus foetidus, mala planinska rijeka, krška rijeka, novi nalaz.

\section{INTRODUCTION}

Sampling of biological elements in rivers and lakes through the national water quality monitoring program (HRVATSKE VODE, 2015) and specific scientific research efforts that cover the ecological and taxonomic aspects of different aquatic organisms (IvKović et al.,

\footnotetext{
* Correspondence e-mail: igorstankovic1@gmail.com
} 
2007; StAnKović et al., 2012, Žutinić et al., 2014), often miss out small mountain rivers, or investigate only their springs and spring areas that are interesting as Dinaric biodiversity hot-spots (Ivкоvić \& Plant, 2015). Therefore, the identification of new species making a contribution to Croatian biodiversity is focused on other types of freshwater habitats (STANKOvić \& TERnJej, 2007). Bijela rijeka River, one of the main water suppliers of the most famous Croatian Plitvice Lakes National Park was investigated in detail in the past (Kostić-Brnek \& Brnek-Kostić, 1965; MatoničKin \& Pavletić, 1967), but in recent years, only its spring area has been studied (Ivкović et al., 2010; MičEtić STANKović et al., 2015). In 2015, research into water quality based on biological quality elements in Bijela rijeka River was conducted, covering the spring area and the main water course including one of five small artificial lakes with occasional connections to the river (STANкоvić \& Leitner, 2015). One of the interesting results was the first observation of the chrysophyte Hydrurus foetidus (Villars) Trevisan in Croatia. The presence of $H$. foetidus is an exceptional example of coldwater stenotherm species occurring in the Bijela rijeka River (WeHR et al., 2015). This finding contributes to the biodiversity of Croatian algal flora and to our better knowledge of the present state of ecological conditions in this small, karstic mountain river. Together with the first identification of the taxon in Croatia, we provide a habitat description including basic hydromorphological, physical and chemical water characteristics, as well as a detailed algal taxonomic list on the observed taxa on this specific site in the Bijela rijeka River.

\section{MATERIALS AND METHODS}

\section{Study area}

Bijela rijeka River is a small, karstic mountain river with a total catchment size of $11.93 \mathrm{~km}^{2}$ (StAnKović \& LeITneR, 2015). It is part of the Black Sea watershed positioned

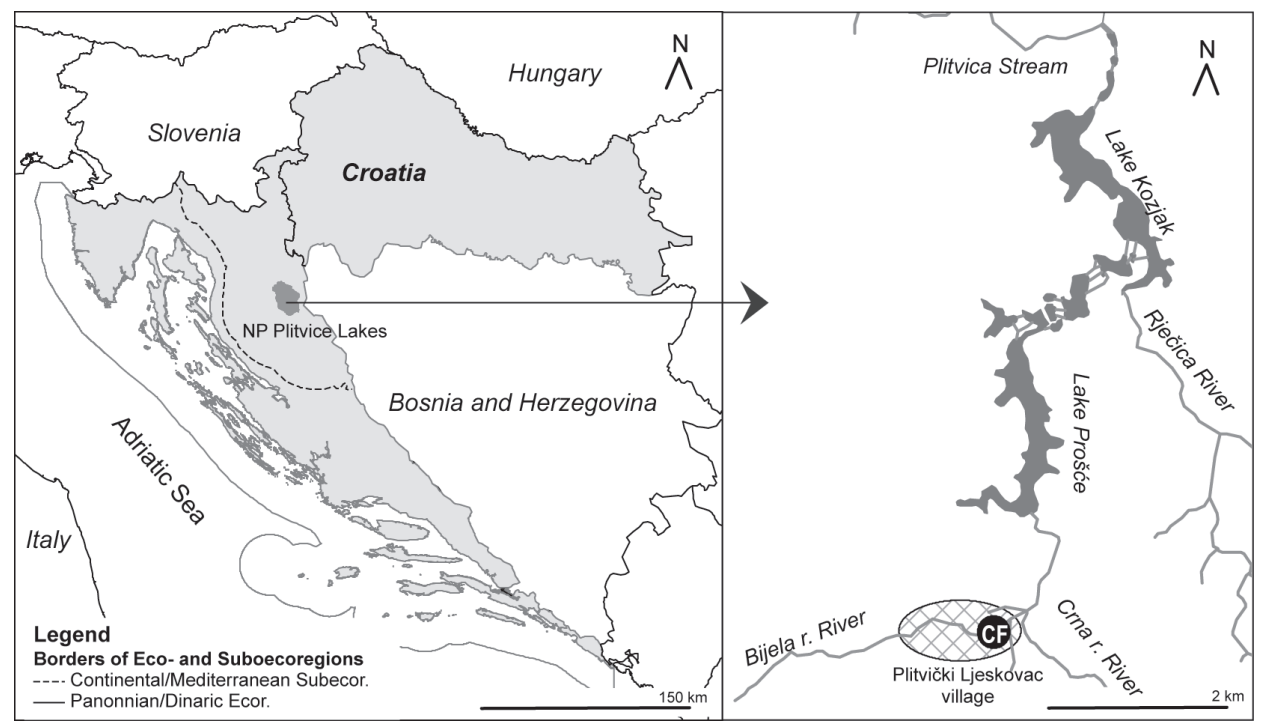

Fig. 1. Map indicating the exact location of the first observation of Hydrurus foetidus in Croatia (HF). 
in the Continental Subecoregion of the Dinaric Ecoregion of Croatia (Hrvatske vode, 2015). Bijela rijeka River, together with Crna rijeka River, belongs to the spring area of Plitvice Lakes protected by UNESCO as a world natural heritage site since 1979 (STILINOVIĆ \& BožIČEvić, 1998). These two rivers are the main water source for the famous 16 cascade lakes in the Plitvice Lakes National Park. Bijela rijeka River originates from a small rheocrene spring at $720 \mathrm{~m}$ a.s.l. and after a course of $4 \mathrm{~km}$ through the forest edges and Plitvički Ljeskovac village, it merges with Crna rijeka River and creates the short Matica River, which flows further into the lakes.

\section{Sampling and analysis of algae}

Sampling and analysis of algae was done according to the Croatian Methodology of sampling, laboratory analysis and determination of ecological quality ratio of biological elements (National Gazette, 73/13, National Gazette, 78/15, National Gazette, 151/14) based on CEN standard HRN EN 15708:2010. Multi habitat sampling of phytobenthos in Bijela rijeka River was conducted in May 2015 during investigation of biological elements for indication of the ecological status of the river (STANKović \& LEITNER, 2015). Algae were collected in two ways: small algae growing on rocks were scraped with a toothbrush, while macroalgae were handpicked or taken by tweezers. In total, four samples were taken, stored in plastic bottles and preserved with $4 \%$ formaldehyde for further analysis. One sample was scraped from rocks and the other three samples were handpicked macroalgae: Zygnema sp., Vauscheria sp. and H. foetidus. Based on estimated abundance in river and abundance under the microscope, the final abundance of each taxon was estimated (HRN EN 15708:2010).

For microscopic analysis 400-1000x magnification was used. H. foetidus was identified according to STARMACH (1985). Other algae were identified at the lowest taxonomic level possible, using up to date identification manuals (Cox, 1996; Eloranta et al., 2011; Ettl et al., 2009; John et al., 2002; KomÁreK \& AnAgnostidis, 2000, 2005; KomÁreK \& Büdel, 2013; Krammer \& Lange-Bertalot, 2008, 2010, 2011).

\section{Analysis of physical and chemical properties of water}

The analysis of the physical and chemical properties of water was done within the water quality monitoring of the Dr. Ivo Pevalek Science Research Centre, Plitvice Lakes National Park. Water depth and water velocity were measured at 20 points throughout the sampling section with Flo-Mate Marsh McBirney 2000.

\section{RESULTS}

Hydrurus foetidus (Villars) Trevisan was identified for the first time in Croatia in Bijela rijeka River on the sampling site in Plitvički Ljeskovac village (N4450'30.9", $\mathrm{E} 15^{\circ} 35^{\prime} 47.5^{\prime \prime}$ ). It was macroscopically visible, dark brown, $10 \mathrm{~cm}$ in length with slippery feel to it, attached to a small twig (Fig. 2a). After microscopical analysis, one characteristic chromatophore was visible on the top of the ovoid cells grouped in formations resembling branches (Fig. 2b-d).

\section{Description of the sampling site}

Both river banks of the Bijela rijeka River are under strong anthropogenic influence, especially the left bank that extends next to the margin of an asphalt road stabilized with 

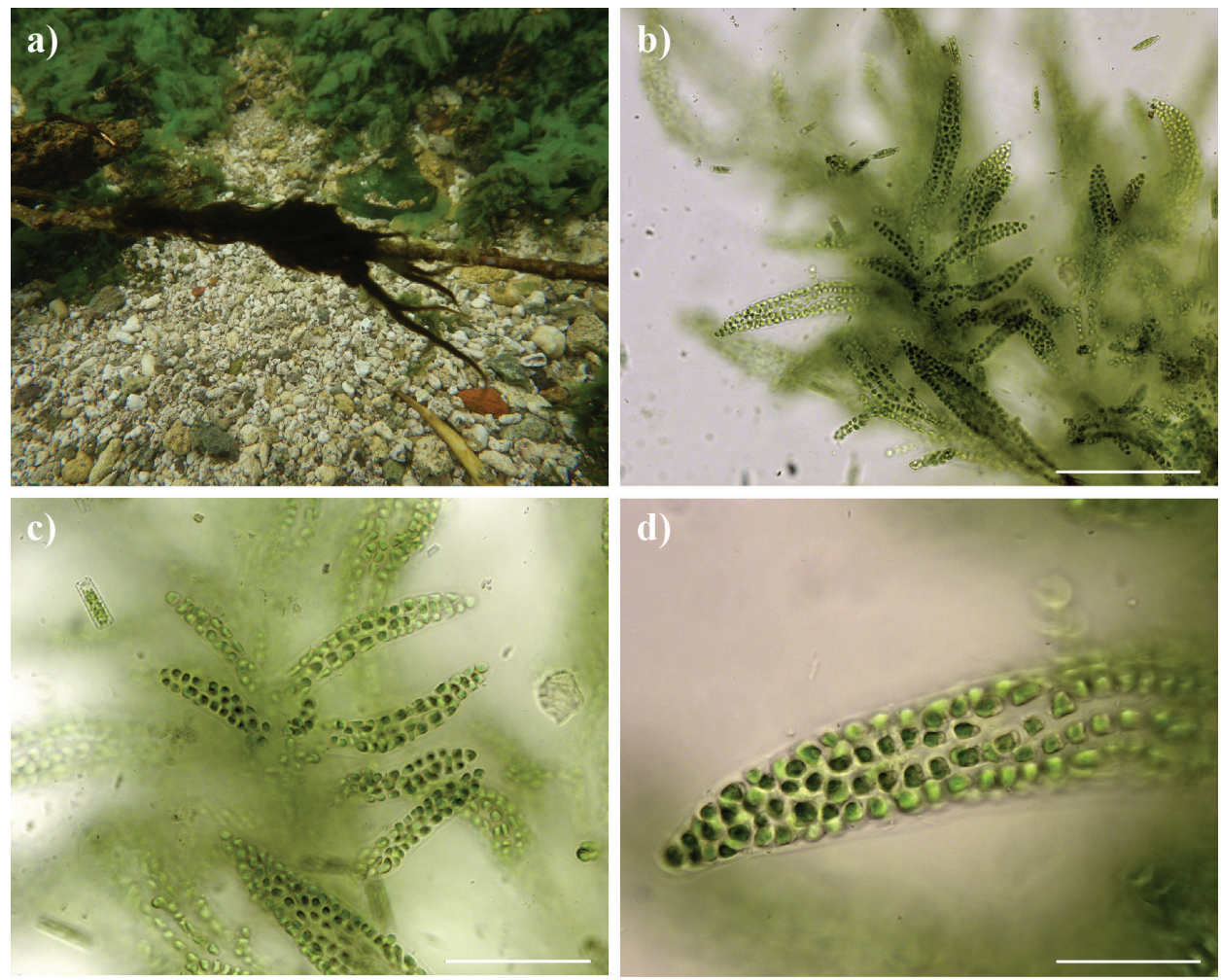

Fig. 2. a) Habitus of Hydrurus foetidus (dark brown) with Zygnema sp. in the background (green); b) Hydrurus foetidus on 100x magnification (BF, scale $=200 \mu \mathrm{m}$ ); c) Hydrurus foetidus on 200x magnification $(\mathrm{BF}$, scale $=100 \mu \mathrm{m})$; d) Hydrurus foetidus on 400x magnification $(\mathrm{BF}$, scale $=50 \mu \mathrm{m})$.



Fig. 3. Sampling site of the first observation of Hydrurus foetidus: Bijela rijeka River in Plitvički Ljeskovac village, Croatia. 
Tab. 1. List of algae found in Bijela rijeka River at a sampling site in Plitvički Ljeskovac village coexisting together with Hydrurus foetidus.

\begin{tabular}{|c|c|}
\hline Taxa List & Relative abundance \\
\hline \multicolumn{2}{|l|}{ Cyanobacteria } \\
\hline Chamaesiphon incrustans Grunow & 2 \\
\hline Chroococcus turgidus (Kützing) Nägeli & 1 \\
\hline Hyella fontana Huber \& Jadin & 1 \\
\hline Merismopedia glauca (Ehrenberg) Kützing & 1 \\
\hline Microcoleus autumnalis (Gomont) Strunecky, Komárek \& J.R.Johansen & 3 \\
\hline Oscillatoria sp. & 2 \\
\hline Oscillatoria tenuis C.Agardh ex Gomont & 2 \\
\hline Phormidium sp. & 2 \\
\hline Pseudanabaena sp. & 1 \\
\hline Tapinothrix janthina (Bornet \& Flahault) Bohunická \& J.R.Johansen & 3 \\
\hline \multicolumn{2}{|l|}{ Charophyta } \\
\hline Zygnema sp. & 4 \\
\hline \multicolumn{2}{|l|}{ Ochrophyta: Bacillariophyceae } \\
\hline Amphora sp. & 1 \\
\hline Achnanthidium spp. & 4 \\
\hline Cocconeis placentula Ehrenberg & 2 \\
\hline Cyclotella meneghiniana Kützing & 1 \\
\hline Cymbella spp. & 2 \\
\hline Diatoma mesodon (Ehrenberg) Kützing & 1 \\
\hline Diatoma tenuis C.Agardh & 1 \\
\hline Diatoma vulgaris var. capitulata Grunow & 3 \\
\hline Diploneis sp. & 1 \\
\hline Gomphonema spp. & 1 \\
\hline Meridion circulare (Greville) C.Agardh & 1 \\
\hline Navicula lanceolata Ehrenberg & 1 \\
\hline Navicula spp. & 2 \\
\hline Navicula tripunctata (O.F.Müller) Bory & 1 \\
\hline Nitzschia spp. & 1 \\
\hline Ulnaria ulna (Nitzsch) P.Compère & 3 \\
\hline \multicolumn{2}{|l|}{ Ochrphyta: Chrysophyceae } \\
\hline Hydrurus foetidus (Villars) Trevisan & 1 \\
\hline \multicolumn{2}{|l|}{ Rhodophyta } \\
\hline Audouinella hermannii (Roth) Duby & 1 \\
\hline \multicolumn{2}{|l|}{ Xantophyta } \\
\hline Vaucheria sp. & 1 \\
\hline
\end{tabular}


rocky blocks (Fig. 3). Dominant substrate of the river bed is microlithal and mesolithal, overgrown by mosses and the macroalga Zygnema sp. attached to mosses. The river's width is 5-7 m. The sampling site is just upstream of the confluence of Ljeskovac Stream.

\section{Physical and chemical properties of water}

Water temperature was $9.0^{\circ} \mathrm{C}$, $\mathrm{pH}$ was 8.3 and conductivity was $441 \mu \mathrm{Scm}^{-1}$. Oxygen concentration was $11.02 \mathrm{mgL}^{-1}$, COD was $1.32 \mathrm{mgO}_{2} \mathrm{~L}^{-1}$ while alkalinity was $259.5 \mathrm{mg}$ $\mathrm{CaCO}_{3} \mathrm{~L}^{-1}$. With regard to nutrients, ammonia was not detected in the water, nitrites were $0.003 \mathrm{mgNL}^{-1}$, nitrates $0.759 \mathrm{mgNL}^{-1}$ and orthophosphates were $0.025 \mathrm{mgPL}^{-1}$.

Water velocity in Bijela rijeka River in Plitvički Ljeskovac village was $0.16-1.01 \mathrm{~ms}^{-1}$ where the average water velocity was $0.60 \mathrm{~ms}^{-1}$. In the sampling stretch, the depth of Bijela rijeka River ranged between 20 and $25 \mathrm{~cm}$, with an average depth of $23 \mathrm{~cm}$.

\section{Taxonomic composition of benthic algae}

Hydrurus foetidus was found growing only on one spot in Bijela rijeka River, therefore its relative abundance was low (Tab. 1). The dominant alga was Zygnema sp., which overgrew mosses in the stream, covering $50 \%$ of the river bed. The other $50 \%$ of the river bed represented by microlithal and mesolithal was covered with a thick layer of algae, mostly composed of diatoms (Achnanthidium sp., Cocconeis placentula, Diatoma vulgaris var. ehrenbergii, Ulnaria ulna, etc.) and cyanobacteria (Chamaesiphon incrustans, Microcoleus autumnalis, Tapinothrix janthina, etc.). In addition to H. foetidus and Zygnema sp., a third macroalga was found in Bijela rijeka River in Plitvički Ljeskovac village and was identified as Vaucheria sp. It was found at only few spots on the river bed, covering small surface and therefore assessed as having low relative abundance.

\section{DISCUSSION}

Recent phycological studies in Croatia have mainly focused on lake and river phytoplankton (Gligora et al., 2007; Gligora Udovič et al., 2015; Stanković et al., 2012). Benthic algae or phytobenthos are rarely in the focus of interest, although it is investigated in the Pannonian ecoregion, more specifically in the Danubian floodplain (ŽUna PFEIFFer et al., 2015). Benthic algae have also been investigated in experiments on tufa barriers and artificial substrates in karstic lakes (Kralj et al., 2006; PlenKović-Moraj et al., 2002), but never in small mountainous rivers. Our first observation of the chrysophyte macroalga $H$. foetidus drew our attention to the fact that common algae like $H$. foetidus in cold mountain rivers (KRIZMANIĆ et al., 2008; WeHr et al., 2015) are not extensively enough studied.

WeHR et al. (2015) state that is H. foetidus is not only a cold stenotherm species, but it is also restricted to riffles with strong current velocity, and has a higher metabolic demand for nutrients. Despite the sufficient nutrient concentration and the high water velocity shown in our study potentially making Bijela rijeka River a perfect habitat for H. foetidus, it was not the dominant taxon. Instead, Zygnema sp. Was characteristically dominant, although this taxon has habitat preferences that are opposite (WeHR et al., 2015). One possible explanation could be that $H$. foetidus disappears above $10^{\circ} \mathrm{C}$ (STARМАСн, 1985), whereas our observation was slightly below this limit.

Our first observation of $H$. foetidus in Croatia draws attention to the importance of future phycological studies of mountain streams. Those studies might clarify the sea- 
sonal dependency of the benthic algae of Bijela ijeka River, contributing, furthermore, to a better understanding of the role of algal biodiversity and its functioning in pristine Croatian mountainous habitats.

\section{ACKNOWLEDGMENTS}

The authors would like to thank Andrijana Brozinčević for help in organizing this project, Maja Vurnek for help in the field sampling, together with Suzana Vuković and Nikola Markić for sampling and water chemistry analysis. We would also like to thank Vlatka Mičetić Stanković for a detailed review of the literature. Presented results are findings from the scientific project "Estimation of the status of spring area Plitvice Lakes (Bijela rijeka River) based on the biological water quality elements with respect to the referent conditions".

Received April 30, 2016

\section{REFERENCES}

Cox, E. J., 1996: Identification of Freshwater Diatoms from Live Material, Chapman \& Hall, London.

Eloranta, P., Kwandrans, J. \& Kusel-Fetzmann, J., 2011: Süßwasserflora von Mitteleuropa 7. Rhodophyta and Phaeophyceae, Spektrum Akademischer Verlag, Heidelberg.

Ettr, H., Georloff, J. \& Heynig, H., 2009: Süßwasserflora von Mitteleuropa, Bd 3: Xanthophyceae 1.Teil, Springer-Verlag, Heidelberg.

Gligora, M., Plenković Moraj, A., Kialj, K., Grigorszky, I. \& Peroš-Pucar, D., 2007: The relationship between phytoplankton species dominance and environmental variables in a shallow lake (Lake Vrana, Croatia). In: Gulati, R. D., Lammens, E., Pauw, N. \& Donk, E. (eds.), Shallow Lakes in a Changing World: Proceedings of the 5th International Symposium on Shallow Lakes, held at Dalfsen, The Netherlands, 5-9 June 2005. Springer Netherlands, Dordrecht, p. 337-346.

Gligora Udovič, M., Žutinić, P., Kralj Borojević, K. \& Plenković-Moraj, A., 2015: Co-occurrence of functional groups in phytoplankton assemblages dominated by diatoms, chrysophytes and dinoflagellates. Fundamental and Applied Limnology 18(2), 101-111.

HRN EN 15708:2010, Kvaliteta vode - Savjetodavna norma za ispitivanje, uzorkovanje i laboratorijsku analizu fitobentosa u plitkim tekućicama (Water quality - Guidance standard for the surveying, sampling and laboratory analysis of phytobenthos in shallow running water (EN 15708:2009)).

HRVATSKE VODE, 2015: Nacrt Plana upravljanja vodnim područjima 2016. - 2021. (Draft River Basin Management Plan 2016. - 2021.), Hrvatske vode, Zagreb, Hrvatska.

Ivкović, M., Kepćija Matonićkin, R., Mihaljević, Z. \& Horvat, B., 2007: Assemblage composition and ecological features of aquatic dance flies (Diptera, Empididae) in the Cetina River system, Croatia. Fundamental and Applied Limnology 170(3), 223-232.

Ivкović, M., MilišA, M. \& Minaljević, Z., 2010: The aquatic dance flies fauna (Diptera, Empididae: Hemerodromiinae and Clinocerinae) of the Plitvice Lakes National Park. Natura Croatica 19(1), 133-139.

Ivкоvić, M. \& Plant, A., 2015: Aquatic insects in the Dinarides: identifying hotspots of endemism and species richness shaped by geological and hydrological history using Empididae (Diptera). Insect Conservation and Diversity 8(4), 302-312.

John, D. M., Whitton, B. A., Вrook, A. J., Society, B. P. \& Museum, N. H., 2002: The Freshwater Algal Flora of the British Isles: An Identification Guide to Freshwater and Terrestrial Algae, Cambridge University Press.

KomÁreK, J. \& ANAGnostidis, K., 2000: Süßwasserflora von Mitteleuropa, Bd. 19/1: Cyanoprokaryota: Chroococcales, Spektrum Akademischer Verlag, Heidelberg.

KomÁreK, J. \& AnAGnostidis, K., 2005: Süßwasserflora von Mitteleuropa, Bd. 19/2: Cyanoprokaryota: Oscillatoriales, Spektrum Akademischer Verlag, Heidelberg.

KomÁREK, J. \& BüDEL, B., 2013: Süßwasserflora von Mitteleuropa, Bd. 19/3: Cyanoprokaryota: Heterocytous Genera, Spektrum Akademischer Verlag, Heidelberg. 
Kostić-Brnek, L. \& BRnek-Kostić, A., 1965: Prvi rezultati saprobioloških istraživanja na Plitvičkim jezerima i okolnim vodama. Plitvički bilten 1(1), 7-18.

Kralj, K., Plenković-Moraj, A., Gligora, M., Primc-Habdija, B. \& Šipoš, L., 2006: Structure of Periphytic Community on Artificial Substrata: Influence of Depth, Slide Orientation and Colonization Time in Karstic Lake Visovačko, Croatia. Hydrobiologia 560(1), 249-258.

Krammer, K. \& Lange-Bertalot, H., 2008: Bacillariophyceae 3.Teil: Centrales, Fragilariaceae, Eunotiaceae, Spektrum Akademischer Verlag, Heidelberg.

Krammer, K. \& Lange-Bertalot, H., 2010: Süßwasserflora von Mitteleuropa 2. Bacillariophyceae 1. Teil: Naviculaceae, Spektrum Akademischer Verlag, Heidelberg.

Krammer, K. \& Lange-Bertalot, H., 2011: Süßwasserflora von Mitteleuropa, Bd. 02/4: Bacillariophyceae: Teil 4: Achnanthaceae, Kritische Ergänzungen zu Achnanthes s.l., Navicula s.str., Gomphonema, Gesamtliteraturverzeichnis Teil 1-4, Ergänzter Nachdruck, 2004, Spektrum Akademischer Verlag.

Krizmanić, J., Subakov-Simić, G. \& Karadžić, V., 2008: Supplementary notes on the distribution of Hydrurus foetidus (Vill.) Trevisan (Chrysophyta) in Serbia. Archives for Biological Sciences 60(2), 13-14.

MatoničKin, I. \& Pavletić, Z., 1967: Hidrologija potočnog sistema Plitvičkih jezera i njegove ekološkobiocenološke značajke. Krš Jugoslavije, JAZU, Zagreb 5, 83-126.

Mičetić Stanković, V., Jäch, M. A. \& Kučinić, M., 2015: Annotated checklist of Croatian riffle beetles (Coleoptera: Elmidae). Natura Croatica: periodicum Musei historiae naturalis Croatici 24(1), 93-109.

National GaZette, 73/13: Uredba o standardu kakvoće voda (Regulation of water quality standard)

National Gazette, 78/15: Uredba o izmjenama i dopunama Uredbe o standardu kakvoće voda (Regulation of changes and updates of Regulation of water quality standard).

National GazetTe, 151/14: Uredba o izmjenama i dopunama Uredbe o standardu kakvoće voda (Regulation of changes and updates of Regulation of water quality standard).

Plenković-Moraj, A., Horvatinčić, N. \& Primc-Habdija, B., 2002: Periphyton and its role in tufa deposition in karstic waters (Plitvice Lakes, Croatia). Biologia 57(4), 423-431.

Stanković, I. \& Leitner, P., 2015: Procjena stanja izvorišnog područja Plitvičkih jezera (Bijela rijeka) u odnosu na referentno stanje na temelju bioloških elemenata. Hrvatsko Botaničko Društvo, Zagreb, 114.

Stanković, I. \& Ternjej, I., 2007: The first record of Cyclops bohater Kozminski (Copepoda, Cyclopoida) in Croatia and the Balkan peninsula. Natura Croatica 16(3), 189-199.

Stanković, I., Vlahović, T., Gligora Udovič, M., Várbíró, G. \& Bórics, G., 2012: Phytoplankton functional and morpho-functional approach in large floodplain rivers. Hydrobiologia 698(1), 217-231.

Starmach, K., 1985: Süßwasserflora von Mitteleuropa, Bd. 1. Chrysophyceae und Haptophyceae, Gustav Fischer Verlag, Stuttgart.

Stilinović, B. \& BožIČEvić, S., 1998: The Plitvice Lakes - a natural phenomenon in the middle of the Dinaric karst in Croatia. European Water Management (1461-6971) 1(5), 15-24.

Wehr, J. D., Sheath, R. G. \& Kociolek, R. P., 2015: Freshwater Algae of North America: Ecology and Classification, Second edn, Academic Press, Amsterdam.

Žuna Pfeiffer, T., Mihaljević, M., Špoljarić, D., Stević, F. \& Plenković-Moraj, A., 2015: The disturbance-driven changes of periphytic algal communities in a Danubian floodplain lake. Knowledge and Managemen $t$ of Aquatic Ecosystems 416, 15.

Žutinić, P., Gligora Udovič, M., Kralj Borojević, K., Plenković-Moraj, A. \& Padisák, J., 2014: Morphofunctional classifications of phytoplankton assemblages of two deep karstic lakes. Hydrobiologia 740(1), 147-166. 


\section{SAŽETAK}

\section{Prvi nalaz alge Hydrurus foetidus (Villars) Trevisan (Ochrophyta: Chrysophyceae) u Hrvatskoj i njezine osnovne ekološke značajke}

\section{Stanković \& P. Leitner}

Hydrurus foetidus (Villars) Trevisan je makroskopski vidljiva alga iz skupine zlatnožutih algi (Ochrophyta: Chrysophyceae), koja je po prvi puta utvrđena u Hrvatskoj tijekom istraživanja fitobentosa, makrofita i makrozoobentosa u 2015. godini u Bijeloj rijeci u NP Plitvička jezera. Alga $H$. foetidus je stenotermna vrsta i isključivi stanovnik hladnih gorskih tekućica, koja preferira plitke dijelove s brzom vodenom strujom. S obzirom na ekološke karakteristike ove makroalge, može se reći kako je Bijela rijeka, kao hladna mala gorska tekućica savršeno stanište za nju. Alga $H$. foetidus je u Bijeloj rijeci utvrđena u naselju Plitvički Ljeskovac, gdje je maksimalna dubina vode samo $25 \mathrm{~cm}$, a izmjerena brzina strujanja vode je dosezala $1.01 \mathrm{~m} / \mathrm{s}$. Nalaz ove alge u Bijeloj rijeci ukazuje na visoku kvalitetu vode, unatoč njenoj hidromorfološkoj degradiranosti i antropogenom utjecaju naselja Plitvički Ljeskovac. Značaj ovog istraživanja nije samo u otkrivanju nove vrste makroalge i doprinos poznavanju bioraznolikosti u Hrvatskoj, već je ono rezultat jednog od prvih današnjih sistematičnih istraživanja gorskih tekućica. 